\title{
Physico-Mechanical Properties of Wood-Plastic Produced with Forest Species and Thermoplastic Materials
}

\author{
Yonny Martinez-Lopez ${ }^{1}$ (D) 0000-0001-7141-4823 \\ Juarez Benigno Paes ${ }^{1}$ (1) 0000-0003-4776-4246 \\ Fabricio Gomes Gonçalves ${ }^{1}$ (i) 0000-0003-2010-9508 \\ Emilio Martínez-Rodríguez ${ }^{2}$ (1) 0000-0001-8762-418X \\ Pedro Nicó de Medeiros Neto ${ }^{1}$ (1) 0000-0001-5647-0050
}

\begin{abstract}
This research aims to evaluate the physico-mechanical properties of wood-plastic composites produced with recycled polyethylene terephthalate, high-density polyethylene, low-density polyethylene and polypropylene, and sawdust from the following species: Pinus caribaea, Pinus cubensis, Cedrela odorata, Talipariti elatum and Eucalyptus sp. Composites were obtained by extrusion with dimension of $1,000 \times 250 \times 16 \mathrm{~mm}$ (length $\times$ width $\times$ thickness), through six treatments. The following physico-mechanical properties were evaluated: density, moisture content, water absorption and thickness swelling, compression, static bending and traction. Treatment 6 obtained the best results, with $1,060 \mathrm{~kg} \mathrm{~m}^{-3}$ density, $5.23 \%$ moisture content, $0.32 \%$ water absorption, and $0.18 \%$ thickness swelling. Compressive strength was $138.10 \mathrm{MPa}$, static bending 18.53 MPa, and traction 29.4 MPa. The technology developed has prospects for large-scale production.
\end{abstract}

Keywords: forestry industry, recycling, wastes.

\section{INTRODUCTION}

Wood-plastic composites (WPC) are produced by mixing plastic waste and vegetable fibers and have become of great interest to science, engineering and civil construction. This panel type generally achieves both good physical and mechanical properties, and its technical information favors decisions on its use (García-Velázquez et al., 2013).

Waste accumulation is related to the evolution in woodand plastic-processing technologies, which has increased waste production. Technological improvements have reduced pollution and scarcity of natural resources. Yet, wood products are underused, as well as other industries. Sawdust and plastics, for example, without higher added value, are stored in large areas and burnt in boilers or open spaces, causing environmental damage (Canastero, 2014).

Wood residues can be used in pulp and paper production, and the sawdust from some species of hardwood, when decomposed, can be used as an organic compound. Although these wastes have good prospects as a raw material for the panel industry, they are used solely as fuel in some countries (Martínez-López et al., 2012).

Another good-prospect raw material for panel industry are recycled plastic materials, a real and advantageous alternative that creates new opportunities and possibilities for their use as they provide good properties to the panels when used with other lignocellulosic materials (Rafighi et al., 2014).

The use of this waste strengthens the forest industry by increasing the value of wood products and diversifying higher quality products. Meanwhile, a research on the use of different forest species and their blending with the properties of panels has been conducted. The quality of this forest product competes with other materials in construction and applications on inner and outer packaging, replacing conventional types (Arnandha et al., 2017).

\footnotetext{
${ }^{1}$ Universidade Federal do Espírito Santo (UFES), Jerônimo Monteiro, ES, Brasil

${ }^{2}$ Estación Experimental Agroforestal Baracoa, Guantánamo, Cuba
} 
Thus, this research was conducted to evaluate physicomechanical properties of wood-plastic composites, produced with recycled thermoplastics and sawdust from coniferous and hardwood forest species. The use of these species provides information on new sources of raw material, as well as their effect on the panel properties.

\section{MATERIAL AND METHODS}

\subsection{Definition of moisture content and sawdust particle size}

Wood residues were obtained from sawmills that process coniferous and hardwood forest species. Then they were shredded in a Wiley mill and classified in suitable dimensions (40-60 mesh) for chemical analysis. For this analysis, $2 \mathrm{~g}$ of sawdust of each species were used in duplicate and oven-dried at $103 \pm 2{ }^{\circ} \mathrm{C}$ until constant mass (approximately 4 hours). Analysis was conducted according to the standards of Technical Association for the Pulp and Paper Industries (TAPPI, 2007) T $264 \mathrm{~cm}-07$. Next, moisture content of the materials was calculated on a dry basis.

To determine the size of sawdust particle to be used in the panels, homogenization and scaling were carried out using a $100 \mathrm{~g}$ sample. It was submitted to a vibrating screen for 30 minutes, and then particles with dimensions between $0.25-5.0 \mathrm{~mm}$ were used to produce the panels, as recommended by Zhang et al. (2012). Figure 1 shows the equipment used in the grinding of particles (hammer mill) and the granulometry used in the technological process.

(a)

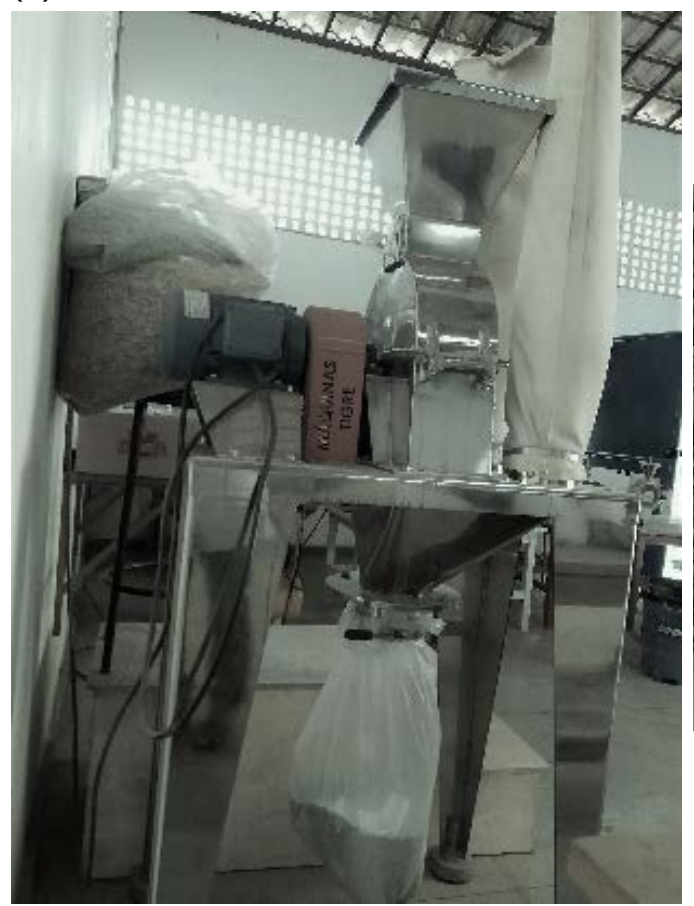

(b)

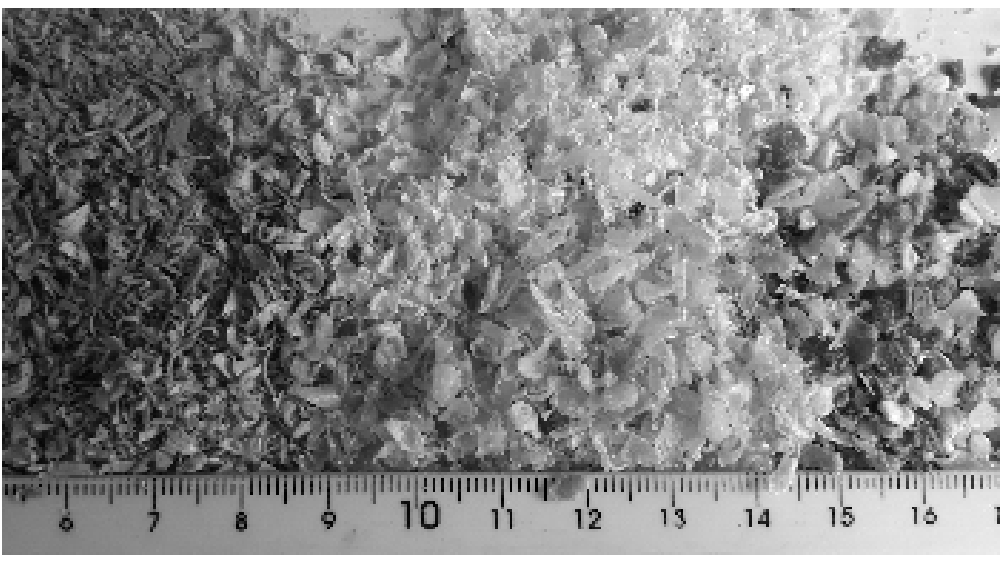

Figure 1. Hammer mill and particle size used.

\subsection{Composition for wood-plastic composites (WPC) production}

WPC were obtained by thermoplastic-wood-additives extrusion in 50-40-10 proportions. A total of six treatments were evaluated and compared to a commercial panel obtained by industry. Dosage is shown in Table 1 .

Calcium carbonate, stearic acid, calcium stearate, zinc stearate and silane $\left(\mathrm{SiH}_{4}\right)$ coupling agent were used in equal proportions up to $10 \%$ as additives. Thermoplastic matrix, polyethylene terephthalate (PET), high-density polyethylene (HDPE), low-density polyethylene (LDPE) and polypropylene (PP) were used in a 3-6 $\mathrm{mm}$ particle size, mixed in equal proportions until reaching $40 \%$ of material proportion for panel production.

Six composites with dimensions of $1,000 \times 250 \times 16 \mathrm{~mm}$ (length $\times$ width $\times$ thickness) were produced for each treatment. Five replicates were evaluated for each of the 
considered properties, which were seven. Each property had 180 samples, totaling 1,260 samples, plus 35 control samples. Physico-mechanical properties were evaluated according to technical norms mentioned in Table 2.

Table 1. Composition of treatments.

\begin{tabular}{cccccccc} 
& \multicolumn{5}{c}{ Thermoplastics (\%) } & $\begin{array}{c}\text { Additive } \\
\text { Treatments }\end{array}$ & $\begin{array}{c}\text { Wood } \\
(\%)\end{array}$ \\
\cline { 2 - 7 } & PET & HDPE & LDPE & PP & 10 & 50 \\
\hline Control & 10 & 10 & 10 & 10 & 10 & 50 \\
\hline T1 & - & 13.33 & 13.33 & 13.34 & 10 & 50 \\
T2 & 13.33 & - & 13.34 & 13.33 & 10 & 50 \\
T3 & 13.33 & 13.34 & - & 13.33 & 10 & 50 \\
\hline T4 & 13.34 & 13.33 & 13.33 & - & 10 & 50 \\
\hline T5 & 10 & 10 & 10 & 10 & 10 & 50 \\
\hline T6 & 10 & 10 & 10 & 10 & 10 & 50 \\
\hline
\end{tabular}

Control: commercial wood-plastic composite; T1: wood-plastic composite (WPC) produced with sawdust from Pinus caribaea; T2: WPC produced with sawdust from Pinus cubensis; T3: WPC produced with sawdust from Cedrela odorata; T4: WPC produced with sawdust from Talipariti elatum; T5: WPC produced with sawdust from Eucalyptus sp. with all thermoplastics; T6: WPC produced with sawdust from the blending of aforementioned species and thermoplastics; PET: polyethylene terephthalate; HDPE: high-density polyethylene; LDPE: lowdensity polyethylene; PP: polypropylene.

Table 2. Technical standards used for physico-mechanical tests of the panels obtained.

\begin{tabular}{|cc}
\hline Standards & Physico-mechanical tests \\
\hline BS EN 317 (1993b) & Samples preparation \\
\hline BS EM 322 (1993d) & Moisture content \\
\hline BS EN 323 (1993e) & Apparent density \\
\hline BS EN 317 (1993b) & $\begin{array}{c}\text { Water absorption at } 72 \mathrm{~h} \\
\text { and thickness swelling }\end{array}$ \\
\hline BS EN 310 (1993a) & Static bending \\
\hline BS EN 319 (1993c) & Traction parallel to faces \\
\hline ASTM D-1037 (2005) & Compression strength \\
\hline
\end{tabular}

BS EN: British Standards European Norm; ASTM: American Society for Testing and Materials.
Mechanical tests were performed in a universal testing machine of 10-ton load capacity coupled to a microcomputer equipped with a specific software program to acquire data from each specimen (Figure 2).

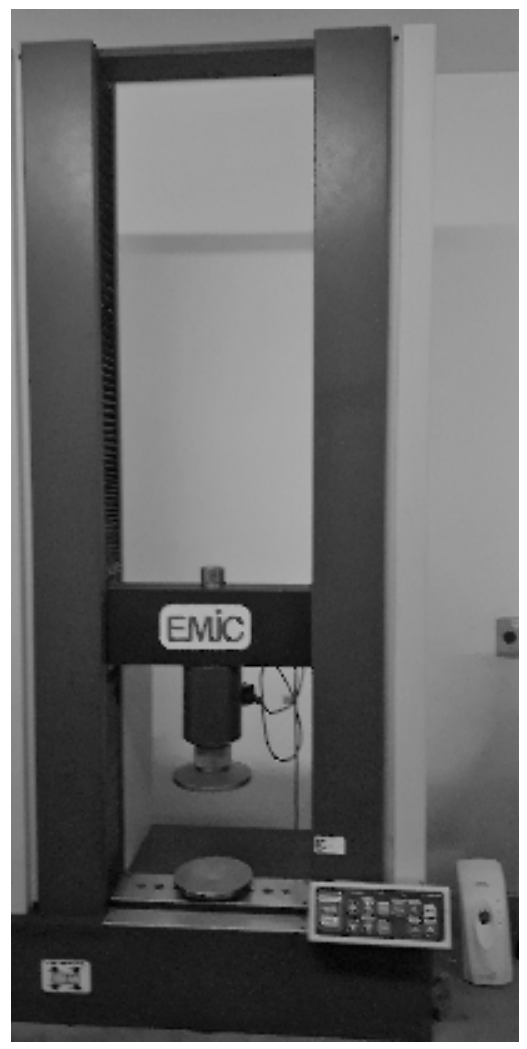

Figure 2. Universal testing machine used to evaluate mechanical resistance of the panels.

\subsection{Statistical evaluation of the results}

As data distribution did not meet normality (KolmogorovSmirnov) and homogeneity of variances (Cochran), the statistical difference between each treatment was analyzed by a non-parametric test (Kruskal-Wallis, $p \leq 0.05$ ), and correlation intervals by the Spearman's test.

The detection of each variable influence on the panel properties was performed by multiple linear regression (MLR) analysis and F-test on partial regression coefficients associated with each independent variable. Then the Stepwise (SWM) method was used to reject independent variables that did not affect the dependent variable, considering interactive effects of independent variables. 


\section{RESULTS AND DISCUSSION}

\subsection{Sawdust moisture content}

Sawdust initial moisture content of studied species were 25\% (Pinus caribaea), 30\% (Pinus cubensis), 35\% (Cedrela odorata), 30\% (Talipariti elatum) and 40\% (Eucalyptus sp.). To reach process suitability, values were reduced to $3-5 \%$.

Similar moisture contents were used by several authors, such as El-Haggar \& Kamel (2011), on composites of Pinus sp. wood sawdust with $3 \%$, and thermoplastics with injection molding. Besides composite moisture content influence, thermoplastic matrix, when forming panels, can produce and encapsulate gases and water (Bouafif et al., 2009; Shebani et al., 2009), generating fault zones within them.

\subsection{Evaluation of the sawdust particle size distribution}

The process of grinding the particles within the hammer mill indicated that for every $1 \mathrm{~m}^{3}$ of sawdust, $88.3 \%$ can be used as a raw material for WPC production, considering that appropriate particle size for this type of panel is between 0.5 and $4 \mathrm{~mm}$ (Martínez-López \& García-González, 2012).

According to Liu et al. (2010), particles bigger than $5 \mathrm{~mm}$ result in low resistance compounds, what may cause irregular concentrations and fault zones, due to low-dispersibility in matrix produced during panel production (Ashori \& Nourbakhsh, 2010; Renner et al., 2009).

\subsection{Physical properties of composites}

Table 3 shows similar behavior among treatments regarding moisture content of the material. For different treatments development, it is important that sawdust has initial moisture content of $\pm 3.5 \%$, as the addition of thermoplastics and chemical additives increased moisture, ranging from 5.23 to $5.63 \%$.

Results obtained by Moya Villablanca et al. (2012) show that the moisture content variation for this kind of panel depends on the amount of sawdust used, considering they may vary from 20 to $60 \%$, and 40 to $60 \%$ of the stability of compounds is due to sawdust. However, moisture content values vary from $3.47-6.78 \%$. Other studies reported similar moisture content for composites made from pinus sawdust and thermoplastics produced by injection molding (El-Haggar \& Kamel, 2011).

Wood particles encapsulation by thermoplastics plays an important role in WPC physico-mechanical properties, as it is a considerable factor for physical properties improvement. This effect can be achieved by thermoplastic matrix within the compound and some additives such as the coupling agent and polyethylene wax, which facilitate the bond between wood particles and thermoplastic matrix and provides impact strength to panels (Garay \& Silva, 2011).

Table 3. Evaluation of physical properties of panels obtained.

\begin{tabular}{|c|c|c|c|c|}
\hline \multirow[b]{2}{*}{ Treatment } & \multicolumn{4}{|c|}{ Physical properties of wood-plastic composites } \\
\hline & $\begin{array}{c}\text { Moisture } \\
\text { content } \\
(\%)^{\star}\end{array}$ & $\begin{array}{l}\text { Apparent } \\
\text { density } \\
\left(\mathrm{kg} \mathrm{m}^{-3}\right)^{\star}\end{array}$ & $\begin{array}{c}\text { Water } \\
\text { absorption } \\
72 \mathrm{~h}^{\star}\end{array}$ & $\begin{array}{l}\text { Swelling } \\
(\%)^{*}\end{array}$ \\
\hline Control & $5.63(0.82)$ & $1,020(1.53)$ & $0.61(1.15)$ & $0.31(0.58)$ \\
\hline $\mathrm{T} 1$ & $5.40(0.84)$ & $1,032(2.08)$ & $0.50(0.96)$ & $0.30(0.71)$ \\
\hline $\mathrm{T} 2$ & $5.42(1.15)$ & $1,035(1.71)$ & $0.50(0.71)$ & $0.30(1.41)$ \\
\hline T3 & $5.34(0.71)$ & $1,037(1.58)$ & $0.40(0.58)$ & $0.28(0.96)$ \\
\hline $\mathrm{T} 4$ & $5.34(0.71)$ & $1,031(2.12)$ & $0.44(0.72)$ & $0.25(0.84)$ \\
\hline T5 & $5.35(0.58)$ & $1,035(1.41)$ & $0.41(0.76)$ & $0.23(1.15)$ \\
\hline T6 & $5.23(0.48)$ & $1,060(0.70)$ & $0.32(0.46)$ & $0.18(0.41)$ \\
\hline
\end{tabular}

Control: commercial wood-plastic composite; T1: wood-plastic composite (WPC) produced with sawdust from Pinus caribaea; T2: WPC produced with sawdust from Pinus cubensis; T3: WPC produced with sawdust from Cedrela odorata; T4: WPC produced with sawdust from Talipariti elatum; T5: WPC produced with sawdust from Eucalyptus sp. with all thermoplastics; T6: WPC produced with sawdust from the blending of aforementioned species and thermoplastics. ${ }^{*}$ Not significant by Kruskal-Wallis test $(p>0.05)$. Values in brackets are standard deviations.

According to studies conducted by Tenorio et al. (2012), the density of the panels may influence physico-mechanical properties. Results presented in Table 3 show a similar behavior in panels density (which ranged from 1,020 to $1,060 \mathrm{~kg} \mathrm{~m}^{-3}$ ). Comparable values were obtained by Ngueho et al. (2010) for thermoplastic compounds with sawdust from different species produced by injection molding, extrusion and compression.

Density values of $1,100 \mathrm{~kg} \mathrm{~m}^{-3}$ were obtained by Beg \& Pickering (2008), using polypropylene (PP) plus 50\% coniferous wood fibers and $4 \%$ chemical additives by injection molding. Adhikary et al. (2008) obtained density values of $1,029 \mathrm{~kg} \mathrm{~m}^{-3}$ using high-density polyethylene (HDPE) plus 50\% Pinus radiata sawdust and 5\% chemical additives by compression molding. Ngueho et al. (2010) obtained density values of $1,080 \mathrm{~kg} \mathrm{~m}^{-3}$ using high-density polyethylene (HDPE) plus 50\% conifer sawdust without additives in extrusion molding.

These results were similar to those obtained in this research, indicating that $50 \%$ sawdust is the most adequate proportion, regardless of the technology used being either extrusion or injection. The difference in this research is 
that several types of recycled thermoplastics were tested, as PET, HDPE, LDPE, PP, and their blends thereof, whose densities may vary from 900 to $1,300 \mathrm{~kg} \mathrm{~m}^{-3}$, especially for HDPE, LDPE and PP which, in addition to wood, increase compounds density (Moya, 2011).

Through studies performed by Poblete \& Vargas (2006) on the relation of physico-mechanical properties to compounds density, and considering results obtained in this research, it can be affirmed that there is a directly proportional relation regarding mechanical properties, and inversely regarding physical properties, as density increase resulted in lower water absorption and swelling, and therefore a lower moisture content caused by thermoplastic matrix effect inside the panel.

Water absorption and swelling percentage (Table 3) is one of WPC advantages, guaranteeing their outdoors usage. According to Deutsches Institut für Normung (1958) criteria - DIN 68750, for particles with density higher than $940 \mathrm{~kg} \mathrm{~m}^{-3}$, absorption after $24 \mathrm{~h}$ water immersion must not exceed $30 \%$. In this sense, when comparing the behavior of the WPC obtained in this research, it was observed that density increase for $72 \mathrm{~h}$ water immersion caused a decrease in water absorption, ranging from 0.32 to $0.61 \%$.

Similar results were obtained by Kuo et al. (2009), with values of $2.96 \%$ in composites made with low-density polyethylene (LDPE), $47 \%$ conifer sawdust and $3 \%$ chemical additives produced by injection molding. However, in employing the same molding method, Zabihzadeh (2010) obtained similar values using $0.50 \%$ of high-density polyethylene (HDPE), 35\% conifer wood sawdust and $2 \%$ chemical additives.

Values of $1.31 \%$ for high-density polyethylene (HDPE), $50 \%$ of conifer sawdust and $3 \%$ of chemical additives were obtained by Adhikary et al. (2008) for panels produced by compression. Ashori \& Nourbakhsh (2010) obtained values of $1.66 \%$ for recycled thermoplastics plus $65 \%$ long fiber sawdust and 6\% chemical additives for panels produced by extrusion molding. Moya (2011) found results of $0.15 \%$ for compounds made from HDPE and $40 \%$ of Pinus radiata sawdust without chemical additives, and values of $0.41 \%$ for HDPE compounds and $60 \%$ of sawdust from the same species and under the same experimental technological conditions.

These results indicate the thermoplastic matrix proportion within composites, in relation to water absorption properties, is improved, i.e. by the encapsulation capacity of the sawdust particles, reducing the possibility of water molecules to penetrate the panel. However, it is also important to note the effect of openings that may occur during panel processing.
Another aspect that can influence panel behavior is the type of technology used: injection, compression or extrusion. Thus, panels produced by injection or extrusion generally present better physical and mechanical properties, due to higher pressures used (El-Haggar \& Kamel, 2011).

Swelling values obtained for each formulation ranged from 0.18 to $0.31 \%$. Similar results were reported by Yadav \& Yusoh (2015) for 2.65\% polypropylene (PP), 60\% sawdust and $1 \%$ chemical additives for composites produced by injection molding.

Adhikari et al. (2008) obtained values of $0.7 \%$ from highdensity polyethylene (HDPE) and 30\% of Pinus radiata sawdust without additives for composites produced by compression, and values of $1.60 \%$ for compounds of high-density polyethylene (HDPE) and 50\% sawdust of the same species. Moya (2011) obtained a value of $0.18 \%$ for compounds produced with high-density polyethylene (HDPE) and 40\% Pinus radiata sawdust without chemical additives, and a value of $0.29 \%$ for compounds processed with HDPE and 60\% sawdust of the same species without additives for panels produced by injection molding.

These interactions can influence the panel behavior towards water because they allow greater dispersion of wood particles or fibers capable of supporting thermoplastic matrix, generating more homogeneous compounds and better physical properties (Rafighi et al., 2014).

Moreover, a favorable WPC performance is the proportionality between wood panels density and swelling. This characteristic is not commonly found in this type of product (Moya Villablanca et al., 2012), as it presents a high density and water has little possibility of penetrating it, preventing any dimensional deformation.

\subsection{Mechanical properties of composites}

Table 4 shows tensile strength values in static bending varying from 15.20 to $18.53 \mathrm{MPa}$, given thermoplastic concentrations and densities of species used. There is an increase in panel density for each treatment (Table 3).

By increasing the density, the tensile strength also increases (Poblete \& Vargas, 2006), also enabled by using calcium carbonate chemical additive, providing better stability for the compound.

Similar results were reported by Moya (2011) using conifer-thermoplastic sawdust proportions of $60-40 \%$ and vice versa, without chemical additives, ranging from 13.20 to 18.56 MPa for injection molding panels. Wang et al. (2010) indicated that increasing wood proportion in panels decreased tensile strength properties. In the present study, 50\% wood 
dosages were established, improving mechanical properties through the blending of all the studied species and chemical additives, which facilitate the connection among particles and improve compound properties.

Table 4. Evaluation of mechanical properties of wood plastic composites.

\begin{tabular}{cccc} 
& \multicolumn{3}{c}{ Mechanical properties of wood-plastic composites } \\
\cline { 2 - 4 } Treatment & $\begin{array}{c}\text { Static bending } \\
(\mathrm{MPa})^{*}\end{array}$ & $\begin{array}{c}\text { Compression } \\
(\mathrm{MPa})^{*}\end{array}$ & $\begin{array}{c}\text { Traction } \\
(\mathrm{MPa})^{*}\end{array}$ \\
\hline Control & $15.20(0.78)$ & $120.18(1.14)$ & $20.3(0.81)$ \\
\hline T1 & $15.35(0.96)$ & $120.20(0.98)$ & $22.4(0.98)$ \\
\hline T2 & $15.38(0.94)$ & $124.26(0.95)$ & $22.7(0.76)$ \\
T3 & $15.38(0.71)$ & $126.26(0.97)$ & $23.7(0.74)$ \\
\hline T4 & $16.34(0.73)$ & $128.24(1.15)$ & $24.4(0.90)$ \\
\hline T5 & $16.43(0.82)$ & $130.31(0.89)$ & $26.2(0.72)$ \\
\hline T6 & $18.53(0.58)$ & $138.10(0.74)$ & $29.4(0.52)$ \\
\hline
\end{tabular}

Control: commercial wood plastic composite; T1: wood-plastic composite (WPC) produced with sawdust from Pinus caribaea; T2: WPC produced with sawdust from Pinus cubensis; T3: WPC produced with sawdust from Cedrela odorata; T4: WPC produced with sawdust from Talipariti elatum; T5: WPC produced with sawdust from Eucalyptus sp. with all thermoplastics; T6: WPC produced with sawdust from the blending of aforementioned species and thermoplastics. ${ }^{*}$ Not significant by Kruskal-Wallis test $(p>0.05)$. Values in brackets are standard deviations.

Table 4 shows compressive strength values which ranged from 120.18 to 138.10 MPa. Moya Villablanca et al. (2012) reported similar results from compounds produced with different ratios of sawdust-plastic and additive, indicating that values may vary from 115 to $140 \mathrm{MPa}$, reinforcing that high wood proportions may cause negative effects on composite strength.

Material compatibility, determined by compression ratio (CR), is a very important factor in panels. This parameter must always be higher than 1 (the ideal value would be between 1.5 and 2.2). Compression ratio for the WPC obtained was approximately 1.73 , considering an overall mean value of $1,035 \mathrm{~kg} \mathrm{~m}^{-3}$ panel density and $600 \mathrm{~kg} \mathrm{~m}^{-3}$ wood density. It reflects the raw material high compatibility, providing good mechanical properties in relation to compression and other properties.

Regarding the tensile strength values parallel to the faces (Table 4), the obtained results were similar for all panels, with variations between 20.3 and 29.4 MPa. Beg \& Pickering
(2008) obtained values of 26.3 MPa for composites produced from recycled polypropylene (PP), 50\% coniferous wood fibers and 3\% additives by injection molding. Rafighi et al. (2014) obtained a reduction of $26.2 \mathrm{MPa}$ for compounds prepared under the same experimental conditions, with $40 \%$ sawdust of the same species, but without chemical additives use. Clemons (2010), however, obtained a value of $17 \mathrm{MPa}$ for HDPE composites with $40 \%$ conifer sawdust and without additives, while Moya Villablanca et al. (2012) found values between 20.7 and $26.7 \mathrm{MPa}$ for similar panels produced with HDPE in various wood proportions and without chemical additives.

These results indicate a positive effect for developed treatments, conferring the importance of using chemical additives. Low-rate of chemical additives will not affect composite properties. Rather, it plays an important role (Clemons, 2010) in favoring the interface between the matrix and the sawdust, by forming bonding esters between cell walls of $\mathrm{OH}^{-}$groups and active groups of coupling agents (Zabihzadeh, 2010).

Studies performed by Ngueho et al. (2010) and Arnandha et al. (2017) showed the effect of the additives on panel mechanical properties. Tensile strength, for example, may decrease with the presence of higher wood proportions in the composite as thermoplastic matrix is reduced. Thus, $10 \%$ of chemical additives were used for treatments tested in this study, and although equal wood and thermoplastic dosages were used, it was found that the additives contributed to the good performance of the panel in terms of mechanical properties.

\subsection{Effects of additives, thermoplastic matrix and sawdust on composites}

Results obtained from Kruskal-Wallis test show no significant difference $(p>0.05)$ in physical and mechanical properties among the tested treatments. Although no statistical differences were found, the formulation with species blending (T6) promoted the best responses to all properties evaluated. Spearman's correlation coefficient, used to evaluate the performance of the properties between the panels showed a 95\% correlation, confirming that when physical properties are better mechanical properties tend to increase.

Multiple linear regression analysis (MRA), to evaluate the relationship between implemented dosages of sawdustthermoplastics-additives and the physico-mechanical properties of composites, was determined by the Stepwise method (SWM) and is shown in Table 5. 
Table 5. Multiple linear regression analysis determined by Stepwise method to physical and mechanical properties of wood-plastic composites.

\begin{tabular}{|c|c|c|c|c|c|c|c|c|}
\hline \multicolumn{9}{|c|}{ Multiple linear regression analysis and Stepwise method } \\
\hline Properties & Parameter & B & EEB & $\mathbf{t}$ & P value & $\mathbf{R}^{2}$ & SEE & Sd \\
\hline \multirow{4}{*}{$\mathrm{D}$} & (Const.) & 516.90 & 2.226 & 356.03 & 0.000 & 0.998 & 6.653 & 0.985 \\
\hline & PS & 10.68 & 0.051 & 210.08 & 0.000 & & & \\
\hline & $\mathrm{PP}$ & -1.762 & 0.183 & -9.635 & 0.001 & & & \\
\hline & \multicolumn{8}{|c|}{ Deleted variable PA } \\
\hline \multirow{4}{*}{ MC } & (Const.) & 10.092 & 0.101 & 100.146 & 0.000 & 0.963 & 0.461 & 0.985 \\
\hline & $\mathrm{PP}$ & -0.088 & 0.013 & -6.970 & 0.000 & & & \\
\hline & PS & -0.031 & 0.010 & -2.964 & 0.004 & & & \\
\hline & \multicolumn{8}{|c|}{ Deleted variable PA } \\
\hline \multirow{3}{*}{ WA } & (Const.) & 13.246 & 0.101 & 131.242 & 0.000 & 0.994 & 0.463 & 0.993 \\
\hline & PS & -0.256 & 0.002 & -105.93 & 0.000 & & & \\
\hline & \multicolumn{8}{|c|}{ Deleted variable PA-PP } \\
\hline \multirow{3}{*}{ ST } & (Const.) & 13.198 & 0.278 & 47.546 & 0.000 & 0.957 & 1.272 & 0.993 \\
\hline & PS & -0.259 & 0.007 & -39.010 & 0.000 & & & \\
\hline & \multicolumn{8}{|c|}{ Deleted variable PA-PP } \\
\hline \multirow{3}{*}{ SB } & (Const.) & 11.590 & 0.226 & 51.397 & 0.000 & 0.789 & 1.054 & 0.993 \\
\hline & PP & 0.108 & 0.007 & 16.075 & 0.000 & & & \\
\hline & \multicolumn{8}{|c|}{ Deleted variable PA-PS } \\
\hline \multirow{3}{*}{$\mathrm{C}$} & (Const.) & 75.573 & 2.145 & 33.829 & 0.000 & 0.873 & 10.021 & 0.993 \\
\hline & PP & 1.392 & 0.064 & 21.807 & 0.000 & & & \\
\hline & \multicolumn{8}{|c|}{ Deleted variable PA-PS } \\
\hline \multirow{4}{*}{$\mathrm{T}$} & (Const.) & 16.406 & 0.239 & 68.771 & 0.000 & 0.929 & 1.093 & 0.985 \\
\hline & PP & 0.453 & 0.030 & 15.059 & 0.000 & & & \\
\hline & PS & -0.212 & 0.025 & -8.616 & 0.000 & & & \\
\hline & \multicolumn{8}{|c|}{ Deleted variable PA } \\
\hline
\end{tabular}

B: coefficient of parameter; $\mathrm{R}^{2}$ : coefficient of determination; EEB: estimative errors; SEE: standard error of estimative; t: t-test design; Sd: standard deviation; MC: moisture content; C: compression; D: density; T: traction; WA: water absorption; ST: thickness swelling; SB: static bending; Const.: constant (property evaluated); PA: percentage of additives; PS: percentage of sawdust PP: percentage of plastic.

These results indicate that, besides density and moisture content, the variables that most influenced the quality of the composites were the sawdust and the plastic percentages, explaining their effects in $96 \%$ of cases in which additive percentage was excluded. Unlike water absorption $(72 \mathrm{~h})$, thickness swelling showed that the variable that most affected the panels behavior was sawdust percentage, affecting over $96 \%$ uninfluenced by plastic and additive percentages. This effect is caused by the wood hygroscopic nature and the presence of hydroxyl groups $\left(\mathrm{OH}^{-}\right)$and carbohydrates that form cell walls in wood, such as cellulose and hemicelluloses.

The behavior of the mechanical properties indicated that the most influential variable for static bending and compression was the thermoplastic percentage, affecting over $80 \%$, as determined by its chemical nature and amorphous structural form, which reinforces wood-plastic composites mechanical properties (Arnandha et al., 2017).

An analysis of sawdust and additive percentages was excluded. However, for tensile strength parallel to the faces, variables that most influenced the panels behavior were thermoplastic and sawdust percentages, explaining their effects in over $92 \%$ (in which percentage of additives was excluded). As shown in each physical-mechanical property, and although additives effect is statistically excluded from the model, the determination that a parameter influences panel properties is supported by the idea expressed by Arnandha et al. (2017), which states that the application of additives is needed for a good panel performance.

Composite obtained in this investigation showed higher values than those obtained by Moya Villablanca et al. (2012). This indicates the positive effect of additives used, of the mixture of recycled thermoplastics tested, as well as of the different forest species in the proportions used in the panel. Furthermore, it showed that additives fulfill their assigned functions, resulting in good interactions between implemented raw materials.

\section{CONCLUSIONS}

Sawdust from different forest species has proven to be important sources of raw materials for wood-plastic composites production, contributing to obtain high-quality 
panels. As these species are widely used in forest industries, it enables the direct use of waste from the primary wood transformation process.

Wood-plastic composites development has great prospects for the panel industry. Its economic feasibility and value-added functions make it a competitive material in relation to other panels produced by industries in this sector.

The compatibility of the type of sawdust used and recycled thermoplastics was showed by compression ratio, which reached 1.73, providing adequate encapsulation of wood particles in thermoplastic matrix and enabling the production of good quality wood-plastic composites.

The best results were obtained for the panel produced by forest species blending. It provided a $1,060 \mathrm{~kg} \mathrm{~m}^{-3}$ density; $5.23 \%$ moisture content; $0.32 \%$ water absorption; and $0.18 \%$ thickness swelling. Static bending was $18.53 \mathrm{MPa}$, compressive strength $138.10 \mathrm{MPa}$ and tensile strength parallel to the faces 29.4 MPa. These values validate their use in different applications as an alternative to construction, conditioning their perspective for industrial diversification.

This study shows the benefits of replacing high-density virgin plastics with thermoplastic waste, such as blending polyethylene terephthalate (PET), high-density polyethylene (HDPE), low-density polyethylene (LDPE) and polypropylene (PP) in equal proportions. These residues can be incorporated into the production process after grinding (particle size up to $6 \mathrm{~mm}$ ).

\section{ACKNOWLEDGEMENTS}

To Fundação Estadual de Amparo à Pesquisa do Estado do Espírito Santo (Fapes) for supporting the research and granting the post-doctoral fellowship to the first author. To the company Emilio Barcenas Pier, Cuba, for the technical support and cession of its facilities for the development of the research.

\section{SUBMISSION STATUS}

Received: 19 May 2016

Accepted: 13 Sept. 2018

Associate editor: Fernando José Borges Gomes

(1) 0000-0003-0363-4888

\section{CORRESPONDENCE TO}

\section{Juarez Benigno Paes}

Universidade Federal do Espírito Santo (UFES), Av. Gov. Lindemberg,

316, Centro, CEP 29550-000, Jerônimo Monteiro, ES, Brasil

e-mail: jbp2@uol.com.br

\section{FINANCIAL SUPPORT}

Fundação Estadual de Amparo à Pesquisa do Estado do Espírito Santo.

\section{REFERENCES}

Adhikary KB, Pang S, Staiger MP. Long-term moisture absorption and thickness welling behaviour of recycled thermoplastics reinforced with Pinus radiate sawdust. Chemical Engineering Journal 2008; 142(2): 190-198. 10.1016/j.cej.2007.11.024

American Society for Testing and Materials - ASTM. ASTM D 1037: standard test methods for evaluating properties of wood-base fiber and particle panel materials. West Conshohocken; 2005.

Arnandha Y, Satyarno I, Awaludin A, Septia I, Prasetya Y, Agung $\mathrm{D}$ et al. Physical and mechanical properties of WPC board from sengon sawdust and recycled HDPE plastic. Procedia Engineering 2017; 171(2017): 695-704. 10.1016/j.proeng.2017.01.412

Ashori A, Nourbakhsh A. Reinforced polypropylene composites: effects of chemical compositions and particle size. Bioresource Technology 2010; 101(7): 2515-2519. 10.1016/j.biortech.2009.11.022

Beg M, Pickering K. Reprocessing of wood fibre reinforced polypropylene composites. Part I: Effects on physical and mechanical properties. Composites Part A: Applied Science and Manufacturing 2008; 39(7): 1091-1100. 10.1016/j.compositesa.2008.04.013

Bouafif H, Koubaa A, Perre P, Cloutier A. Effects of fiber characteristics on the physical and mechanical properties of wood plastic composites. Composites Part A: Applied Science and Manufacturing 2009; 40(12): 1975-1981. 10.1016/j.compositesa.2009.06.003

British Standards. BS EN 310: 1993: wood-based panels: determination of modulus of elasticity in bending and of bending strength. London; 1993a.

British Standards. BS EN 317: 1993: particleboards and fibreboards: determination of swelling in thickness after immersion in water. London; 1993b.

British Standards. BS EN 319: 1993: particleboards and fibreboards: determination of tensile strength perpendicular to the plane of the board. London; 1993c.

British Standards. BS EN 322: 1993: wood-based panels: determination of moisture content. London; 1993d.

British Standards. BS EN 323: 1993: wood-based panels: determination of density. London; 1993e.

Canastero RD. Aprovechamiento de los residuos de la madera y su posible reutilización en fabricación de biomasa generada en Bogotá [thesis]. Bogotá: Universidad Distrital Francisco José de Caldas; 2014.

Clemons C. Elastomer modified polypropylene-polyethylene blends as matrices for wood flour-plastic composites. Composites: Part A: Applied Science and Manufacturing 2010; 41(11): 1559-1569. 10.1016/j.compositesa.2010.07.002

Deutsches Institut für Normung. DIN 68750: Holzfaserplatten, poröse und harte Holzfaserplatten, Gütebedingungen. Berlin; 1958.

El-Haggar SM, Kamel MA. Wood plastic composites. In: Tesinova P, editor. Advances in composite materials: analysis of natural and man-made materials. London: In Tech; 2011. p. 325-344.

Garay M, Silva S. Comportamiento de tableros a base de madera, durante ensayos de atenuación ultrasónica. Revista de la Construcción 2011; 10(3): 41-51. 10.4067/S0718-915X2011000300005

García-Velázquez A, Amado-Moreno M, Casados-Pérez M, BritoPáez R. Madera plástica con PET de post consumo y paja de trigo. Ciencia y Tecnología 2013; 13: 25-40. 10.18682/cyt.v1i13.30 
Kuo PY, Wang SY, Chen JH, Hsueh HC, Tsai MJ. Effects of material compositions on the mechanical properties of wood-plastic composites manufactured by injection molding. Materials \& Design 2009; 30(9): 3489-3496. 10.1016/j.matdes.2009.03.012

Liu H, Yao F, Xu Y, Wu Q. A novel wood flour-filled composite based on macrofibrillar high-density polyethylene (HDPE)/nylon-6 blends. Bioresource Technology 2010; 101(9): 3295-3297. 10.1016/j. biortech.2009.12.073

Martínez-López Y, Fernández-Concepción RR, Álvarez-Lazo D, García-González M, Rodríguez-Álvarez R. Perspectivas para la utilización del aserrín en la producción de tableros madera plástica con propiedades ignifugas. Revista Avances 2012; 14(2): 120-129.

Martínez-López Y, García-González M. Aprovechamiento de los residuos forestales, compilación de autores cubanos. Saarbrücken: Editorial Académica Española; 2012.

Moya C. Compuestos lignocelulósico-plástico obtenidos a partir de harina de madera o corteza de Pinus radiata y polietileno reciclado fabricado mediante moldeo por inyección [dissertation]. Concepción: Universidad de Concepción; 2011.

Moya Villablanca C, Poblete Wilson H, Valenzuela Hurtado L. Propiedades físicas y mecánicas de compuestos de polietileno reciclado y harinas de corteza y madera de Pinus radiata fabricados mediante moldeo por inyección. Maderas, Ciencia y Tecnología 2012; 14(1): 13-29. 10.4067/S0718-221X2012000100002

Ngueho M, Koubaa A, Cloutier A, Soulounganga P, Wolcott M. Effect of bark fiber content and size on the mechanical properties of bark/HDPE composites. Composites Part A: Applied Science and Manufacturing 2010; 41(1): 131-137. 10.1016/j. compositesa.2009.06.005

Poblete W H, Vargas C R. Relación entre densidad y propiedades de tableros HDF producidos por un proceso seco. Maderas, Ciencia y Tecnología 2006; 8(3): 169-182. 10.4067/S0718-221X2006000300004
Rafighi A, Dorostkar A, Madhoushi M. Investigation on mechanical properties of composite made of sawdust and high density polyethylene. International Journal of Lignocellulosic Product 2014; 1(2): 134-141. 10.22069/IJLP.2014.2070

Renner K, Móczó J, Pukánszky B. Deformation and failure of PP composites reinforced with lignocellulosic fibers: effect of inherent strength of the particles. Composites Science and Technology 2009; 69(10): 1653-1659. 10.1016/j.compscitech.2009.03.015

Shebani A, van Reenen A, Meincken M. The effect of wood extractives on the thermal stability of different wood-LLDPE composites. Thermochimica Acta 2009; 481(1-2): 52-56. 10.1016/j.tca.2008.10.008

Technical Association for the Pulp and Paper Industries - TAPPI. TAPPI T $264 \mathrm{~cm}-07$ : solvent extractives of wood and pulp. Atlanta: TAPPI; 2007.

Tenorio C, Moya R, Camacho D. Propiedades físico-mecánicas de tableros terciados construidos con especies tropicales de plantaciones para uso estructural. Cerne 2012; 18(2): 317-325. 10.1590/S010477602012000200017

Wang H, Sheng KC, Lan T, Adl M, Qian XQ, Zhu SM. Role of surface treatment on water absorption of poly(vinyl chloride) composites reinforced by Phyllostachys pubescens particles. Composites Science and Technology 2010; 70(5): 847-853. 10.1016/j. compscitech.2010.01.023

Yadav S, Yusoh K. Mechanical and physical properties of wood plastic composite made of polypropylene, wood fluor and nanoclay. International Journal of Agriculture, Forestry and Plantation 2015; 1: 52-58.

Zabihzadeh M. Water uptake and flexural properties of natural filler/ HDPE composites. BioResources 2010; 5(1): 316-323.

Zhang Z, Gao C, Xin Z, Kim J. Effects of extruder parameters and silica on physic-mechanical and foaming properties of $\mathrm{PP} /$ wood-fibers composites. Composites Part B Engineering 2012; 43(4): 2047-2057. 10.1016/j.compositesb.2012.01.047 